\title{
THE ROLE OF WOMEN AS EDUCATORS
}

\author{
M. Imamuddin \\ Institut Agama Islam Negeri (IAIN) Bukittinggi, \\ Email: m.imamuddin76@yahoo.co.id \\ Andryadi \\ Institut Agama Islam (IAI) Yasni Bungo, Jambi \\ Email: Andryadi228@gmail.com \\ Zaharuddin. $M$ \\ Institut Agama Islam (IAI) Tebo, Jambi \\ Email: zahar.unu92@gmail.com

\section{Isnaniah} \\ Institut Agama Islam Negeri (IAIN) Bukittinggi \\ Email: iis_imam@yahoo.co.id

\section{Weti Susanti} \\ Sekolah Tinggi Agama Islam Yastis Padang, Indonesia \\ Email: wetisusanti82@gmail.com

\section{Rehani} \\ Universitas Islam Negeri Imam Bonjol Padang \\ Email: rehani@uinib.ac.id

\section{Zulmuqim} \\ Universitas Islam Negeri (UIN) Imam Bonjol Padang \\ Email: zulmuqim@yahoo.co.id

\section{Syafruddin Nurdin} \\ Universitas Islam Negeri (UIN) Imam Bonjol Padang \\ Email: Syaf.nurdzin@gmail.com
}

\begin{abstract}
Abstrak
Dalam Al-Quran dan hadis tidak terdapat larangan bagi perempuan dalam menuntut ilmu. Bahkan sebaliknya, Islam mengharuskan atau mewajibkan perempuan menuntut ilmu pengetahuan seperti halnya kepada laki-laki. Ilmu ibarat cahaya yang akan menerangi langkah kaki perempuan menuju masa depan. Perempuan berilmu pasti terangkat derajatnya. Sebaliknya, perempuan bodoh dan kurang pengetahuan, hanya akan dianggap sebagai makhluk lemah yang bisa diperdayakan, bukan
\end{abstract}

Nur El-Islam, Volume 7, Nomor 2, Oktober 2020 
M. Imamuddin, Andryadi, Zaharuddin....

diberdayakan. Demikian penting ilmu yang dimiliki orangtua terlebih ilmu seorang perempuan (ibu) yang mampu menjadikan jiwa anak berkarakter dan berwatak baik atau buruk, sehingga nya kewajiban atas pendidikan anak tertuju pada kedua orangtua ketika anak masih dalam kandungan hingga sampai anak dewasa. Untuk itu pentinglah seorang perempuan (ibu) memiliki ilmu yang cerdas, baik, agar watak ibu turun pada anak- anak yang ia asuh. Sebagai seorang perempuan (ibu) yang ditugaskan untuk menjadi pengajar pertama bagi anak-anaknya tidak semerta-merta ia hanya mengajarkan yang ia ketahui, ibu yang mampu melahirkan generasi cerdas bagi nusa dan bangsa haruslah pula memiliki kecerdasan dalam dirinya, bagi seorang perempuan tidaklah salah jika memiliki pendidikan yang tinggi agar dapat mencerdaskan anak-anaknya.

Kata kunci: Perempuan, Pendidik

\begin{abstract}
In the Al-Qur'an and Hadith there are not prohibition for women in seeking knowledge. On the contrary, Islam requires or obliges women to seek knowledge as well as men. Science is like light that will illuminate women's footsteps into the future. A woman of knowledge must be elevated. Conversely, women who are ignorant and lack knowledge will only be considered as weak creatures who can be empowered, not empowered. Such is the importance of parent's knowledge, especially the knowledge of a woman (mother) who is able to make a child's soul character and character, good or bad, so that the obligation for children's education is directed at both parents when the child is still in the womb until he reaches adulthood. For this reason it is important for a woman (mother) have to be smart, so that the character of the mother descends on her children. As a woman (mother) who is assigned to be the first teacher for her children does not necessarily teach only what she knows, mothers who are able to give birth an intelligent generation for the homeland and nation must also have intelligence in themselves, for a woman is not wrong if have a high education in order to educate their children.
\end{abstract}

Keyword: Women, Educators

\title{
Background
}

Humans, both men and women are God's creations that occupy the highest glory on this earth. Humans are equipped with reason and intuition in all kinds of conditions. Human presence is the culmination of God's creation. Humans are Abdullah and caliph on this earth. According to the nature of the incident, human beings were created free and independent, in the sense that voluntary work 
without coercion was driven by pure will to achieve the pleasure of Allah SWT as the Creator and so how they could play a role in society. The position of men and women are basically the same in the AlQur'an as a reference to the basic principles of Islamic society. Both of them were created with no advantages over one another. On that basis, the principles of the Al-Qur'an regarding the rights of men and women are the same, where the rights of the wife are recognized fairly with the rights of the husband. Men have rights and obligations towards women, and women also have rights and obligations towards men.

The Al-Qur'an teachings about women are part of an effort to strengthen and also improve the weak position of women in preIslamic Arab society. Islam teachings give a large portion of attention and respectable position to women, can be seen in terms of the origin of its creation and can also be seen in terms of rights or participation in various fields.

The nature of women in the minds of most people, among some experts, and among Muslims themselves often falls on two extreme views. One view holds that women in Islam societies are oppressed, and another view hold that Islam gives women a position that is not match in other religions and cultures. ${ }^{1}$ In the Al-Qur'an and Hadith there are not prohibition for women in seeking knowledge. ${ }^{2}$ On the contrary, Islam requires or requires women to seek knowledge as well as men. Islam gives equal rights for men and women to seek knowledge. Rasulullah also said that studying is an obligation for Muslim men and Muslim women. Before the arrival of Islam, there were already women who could write and read, only that there were still a few in certain circles. After the arrival of Islam women were given the freedom of learning, developing knowledge, women also obtaining social rights that had never been obtaining before the arrival

\footnotetext{
${ }^{1}$ Samsul Nizar dan Zainal Efendi Hasibuan, Hadis Tarbawi Membangun Kerangka Pendidikan Ideal Perspektif Rasulullah, (Jakarta: Kalam Mulia, 2011), h. 142.

${ }^{2}$ Muhammad Munir Mursi, al-Tarbiyyat al-Islamiyat, Ushuliha wa Thathawuriha fi al-Bilad al-Arabiyat, (Kairo: 'Alim al-Kutub, 1982), h. 152.
} 
M. Imamuddin, Andryadi, Zaharuddin....

of Islam. Even the Messenger of Allah affirmed that the best men were the best people towards their wives. ${ }^{3}$

\section{Discussion}

\section{Girl}

The Al-Qur'an, as basic principles or moral guidelines, includes various recommendations for upholding theological (religious), economic, political, cultural, cultural justice including gender justice. ${ }^{4}$ Discretely, in this world who are recognized as "natural" human beings are men and women. Although bearing the title as a human being "common", but there is an imbalance between the two, repression (oppression) that is truly extraordinary. Men control women in various fields of life, this is a reality that cannot be denied by anyone. ${ }^{5}$ The problem of the creation of women are known that women were first created from the ribs of men, in this case the first woman named Sitti Hawa was created by God from the ribs of the Prophet Adam As. the crooked one. This is narrated in the hadith which means as follows:

Meaning: Abu Kuraib and Musa bin Hizam told us, said: Husayn ibn Ali told us, from Ali, from Zaidah, from Maysaarah al-Asyja'iy, from Abu Hazim, from Abu Hurairah ra, said: The Messenger of Allah said: Give each other a message, because actually women are created from crooked ribs, and therefore women are like ribs, if you try to straighten it will break. But if you let it be, then you will enjoy it while still being bent, then you will inherit each other over women. ${ }^{6}$

The hadith illustrates that the crooked ribs are the origin of the creation of women in the universe. However, it can be understood that the meaning and containing of hadith that the creation of women are

${ }^{3}$ Samsul Nizar dan Zainal Efendi Hasibuan, Hadis Tarbawi Membangun Kerangka Pendidikan Ideal Perspektif Rasulullah, (Jakarta: Kalam Mulia, 2011), h. 148.

${ }^{4}$ Mansour Fakih, Analisis Gender dan Transformasi Sosial, Cet. IX, (Yogyakarta: Pustaka Pelajar, 2005), h. 135.

${ }^{5}$ Syafiq Hasyim, Pengantar Feminisme dan Fundamentalisme Islam, Cet. I, (Yogyakarta: LKiS, 2005), h. 5.

${ }^{6}$ Supardin. Kajian Gender Perspektif Hadis Nabi, Kajian Gender Perspektif Hadis Nabi, AL-FIKR, Volume 4817 Nomor 1 Tahun 2013, h. 53. 
very different from the creation of the origin of men that are created from clay. The process of birth or human events after the Prophet Adam and Sitti Hawa, are the same that are through the process of birth, both born of a mother, and women have the same position as men. ${ }^{7}$ However, it is also undeniable that both of them have different characteristics and behaviors, including their posture.

Women were gentle and loving beings because of their delicate feelings. In general the nature of women are beauty, tenderness and humility and nurturing. In addition, women mature faster than men. ${ }^{8}$ An identical women with someone who are domestic tasks such as sweeping, cooking, washing, and carring for her children. ${ }^{9}$ Thus the picture of women who are often heard around us. Anatomical and physiological are different also cause different in their behavior, and different also arise in terms of ability, selective to intentional activities that are aimed and directed towards women's nature.

Scientists such as Plato, said that women in terms of physical and spiritual are strength, mental women are weaker than men, but this different does not cause different in their talents. ${ }^{10}$ While the description of women according to views based on medical, psychological, and social studies, are divided into two factors, namely physical and psychological factors.

Biologically from a physical point of view, women are distinguished from women as smaller than men, their voices are smoother, women's body development occurs earlier, women's strength are not as strong as men's and so on. Women have a calm attitude, women's feelings cry more quickly and even faint when faced with severe problems. ${ }^{11}$

${ }^{7}$ Ibid

${ }^{8}$ M. Imamuddin dan Isnaniah, Kemampuan Spasial Mahasiswa Laki-laki dan Perempuan dalam Menyelesaikan Masalah Geometri, Humanisma: Journal of Gender Studies, 1 (2), 38-47, Juli-Desember 2017

${ }^{9}$ M. imamuddin dkk., Gender Based Perception On Understanding Mathematics Concep By Using PBL, Humanisma: Journal of Gender Studies, 3 (1), 58-74, 2019

${ }^{10}$ Murtadlo Muthahari, Hak-hak Perempuan dalam Islam, (Jakarta: Lentera, 1995), h. 107.

${ }^{11}$ Ibid. h. 108-110. 
While Kartini Kartono said, that the natural physiological differences from birth in general were then strengthened by existing cultural structures, in particular by customs, social systems, economics, and the effects of education. ${ }^{12}$ These cultural and pedagogical influences are directed at the personal development of women according to one pattern of life and one particular idea. Those development were partly adapted to the talents and abilities of women, and partly adapted to general opinions on tradition according to certain feminist criteria.

Existentially, every human being has the same dignity and dignity, so that he is entitled to be respected and treated according to his dignity and dignity. Basically, human rights include, the right to life, the are right to independence, the right to own something, and the right to receive education. These three rights of human nature. Anyone must be not interfered and must be protected. ${ }^{13}$

In the teachings of Islam, all human beings are one creature of God, have the same degree, whatever their cultural background, and therefore have the same appreciation from God that must be respected and glorified. Thus, discrimination based on differences in sex, color, class, race, territorial, ethnicity, religion and so on have not basis at all in the teachings of monotheism. Only the degree of devotion to Allah is the measure of difference later in retaliation. ${ }^{14}$

Muslim women actually have a high position in Islam and are very influential in the lives of every human being. The highest status of these women are:

1. Women are Servants of God

Women have the same responsibilities as men in their position as servants of God, namely having the obligation to devote themselves to Allah SWT. the letter Adz Dzariat verse 56:

${ }^{12}$ Kartini Kartono, Psikologi Perempuan, Mengenal Gadis Remaja dan perempuan Dewasa, (Bandung: Mandar Maju, 1989), h. 4.

${ }^{13}$ Trisakti Handayanirakat, Memperjuangkan Hak Asasi Perempuan, dalam Suara Perempuan, Pusat Studi Perempuan dan Kemasyarakatan, (Malang: UMM, 1996), h. 9.

${ }^{14}$ Hussein Muhammad, Islam Agama Ramah Perempuan, (Yogyakarta: LKiS, 2004), h. 11. 
It means: "And I did not create jinn and men except they might serve $M e^{\prime \prime}$

The essence of human life, including a women are to worship and seek the pleasure of Allah SWT. Worship can include special rituals such as prayer, fasting, almsgiving, and pilgrimage, but also worship which in nature includes all activities of the goodness of life in all aspects. Those can be done through her own personal attachment to the rules that God has set.

2. Women are Society

Women become part of a society. She has a responsibility to the environment and social conditions. This position demands the role of a women are not only in private circumstances, but also in political life. It is mutually accommodating in carrying out the responsibility the Ma'ruf Nahi Munkar. Women must be proficient in taking the practical steps needed to face change of the mind of their society. Women are also needed in their work to preach in society, so that women have qualified knowledge of Islam and the general public.

\section{The Position of Women in Islam}

The Al-Qur'an firmly rejects various forms of oppression of women, defends the position and personality of women, and states to the world's population the value of their existence and freedom. ${ }^{15}$

The nature of the position of women and men are the same before God Almighty. There is no competition between men and women other than the race to reach the pleasure of Allah alone. In another part, they do not only take part in the house, but many women work outside the home. Broadly speaking, there are two reasons that why women are working: economic factors and alternative factors. ${ }^{16}$

\footnotetext{
${ }^{15}$ Hadi Dust Muhammadi, Bukan Perempuan Biasa, (Jakarta : Cahaya, 2005), h. 77.

${ }^{16}$ Khofifah Indar Parawansa, Islam, NU, dan Keindonesiaan, (Bandung: Nuansa Cendikia, 2013), h. 152.
} 
Islam does not distinguish the existence of men and women in their capacity as servants of God, caliphs, and primordial agreements with God. In addition, Islam also does not differentiate between men and women to obtain employment opportunities and achieves the highest achievements in fields that are justified by Islam, but all humans are given the same opportunities and rights so that men and women do not in a healthy manner, without ignoring their respective nature. ${ }^{17}$

In order to prepare to face severe challenges in the present and which become even tougher in the future (21st century), Indonesian Muslim women need and must be able to choose priorities from a series of clear obligations are that the quality of Indonesian Muslim women who the average are still below the standard line of Islamic insights, intellectual conditions and social economic conditions, needs to get first priority. ${ }^{18}$

1.

Women are wife

A women who are currently serving as the head of the household that service as minister of the interior, whose obligations include being responsible to the head of state, and being responsible to all the people and their citizens. The are fully responsible for the security of their household, the security of family and family experts in their household. So if they are clever and capable of controlling and / or leading a household, the name as an honor for herself is certainly given by her husband, which is furthermore by association in the community. ${ }^{19}$

Women were created by God to accompany men, women and men were created to need and complement each other, women and men looked after one another for the harmony of their families. That beautiful wife of her temperament, will make a good husband of his character.

Islam gives status and the main role for women are not as a financial supplier and responsible for the family. But Islam teaches

${ }^{17}$ Hamid Laonso dan Muhammad Jamil. Hukum Islam Alternatif Solusi terhadap Masalah Fiqh Kontemporer, (Jakarta: Restu Ilahi, 2005), h. 77

${ }^{18}$ Ali Akbar, Merawat Cinta Kasih, (Jakarta: Pustaka Antara, 1978), h. 267.

${ }^{19}$ Moenawar Chalil, Nilai Perempuan, (Solo: Ramadhani, 1984), h. 126. 
that obligation is impossed on men, both as husbands or as siblings in off spring. ${ }^{20}$

2 .

Women are housewives

The Al-Qur'an places the obligation to do good to parents especially to mothers in the second place after the obligation to obey God, not only because mothers bear a heavy burden in conceiving, giving birth and breastfeeding children. But also because mother is burdened with the task of creating leaders of the people.

Women are the main stronghold in the family. Improving the quality of human resources starts from the role of women in providing education to their children as the next generation of the nation.

Islam highly respects and rewards to the mother who is truly capable and sufficient to be household leaders, educate children under their care, and provide agreements in the form of glory and elevation or their degree. Because with the leadership of mother, children become Muslims, become leaders of Islam, become judges of Islam and so forth. ${ }^{21}$

How the influence of women's enthusiasm can be seen, for example, during the struggle for independence. Although men must take responsibility for their own decisions, they will continue to work as Republican officials who are in need or as Nica (Natherlands Indies Civil Administration) employees who live in luxury, but it cannot be denied, that in general the nature of the so-called "back line" is greatly influenced their decision, and as long as the mother remained strong, the fathers apparently remained loyal to the ideals of independence. ${ }^{22}$

All forms of tyranny have been removed from them, and Islam has restored its position, and made them as male partners who are equal in matters of reward, torture and all rights, except cases which are specifically reserved for women. Allah subhanahu wa ta'ala said which means:

${ }^{20}$ Fauzie Nurdin, Perempuan Islam dan Transformasi Sosial Keagamaan, (Yogyakarta: Gama Media, 2009), h. 35.

${ }^{21}$ Moenawar Chalil. Nilai Perempuan, (Solo: Ramadhani, 1984), h. 130.

${ }^{22}$ Nani Suwondo. Kedudukan Perempuan Indnesia : Dalam Hukum dan Masyarakat, (Jakarta: Balai Aksara, 1981). h. 242. 
It means: "Whoever does righteous deeds, both men and women in a state of faith, we will surely give them a good life and in fact we will reward them with a reward that is better than what they have done, (Surat Al-Nahl: 97).

Allah subhanahu wa ta'ala said:

It means: "Then their Lord permitted his request (by saying)," Verily I do not waste the deeds of those who do good among you, male or female, (for) some of you are descended from some of the others ", (Surah Ali Imron: 195)

Narrated by Al-Turmudzi from Umm Ummah radhiallahu 'anha that he went to the Prophet Muhammad salallahu' alayhi wasalam and said, "I did not see any guidance except everything for men, I did not see for women a certain guidance, then Allah revealed this verse:

It means: "Verily Muslim men and women, believing men and women, men and women who remain in their obedience, true men and women, patient men and women, men and women solemn women, men and women who give alms, men and women who fast, men and women who maintain their honor, men and women who chant many (names) of Allah, Allah has provided for them forgiveness and merit the big one ", (Surah AlAhzab: 35).

Narrated by Imam Ahmad musnad of Aisha RA that the Prophet Muhammad salallahu 'alayhi wasalam said, which means: "Truly women are siblings of men". ${ }^{23}$

And Islam forbids women as like as men, as happened in the jahiliyah community. Allah subhanahu wa ta'ala said:

It means: "O you who believe, it is not lawful for you to destroy women by force", (Qur'an, Al-Nisa: 19).

${ }^{23}$ Musnad Imam Ahmad: 6/256. 
Then Islam guarantees women's personal independence, making them heirs not inherited goods, Islam also gives part of the inheritance from the relatives. Allah subhanahu wa ta'ala said:

It means: "For men there are a right of part of the inheritance of the mother-father and their relatives, and for women there are a right of part (also) of the inheritance of the mother-father and relatives, either a little or a lot according to the predetermined portion", (QS Al-Nisa ': 7).

Narrated by Al-Bukhari and Muslims from Abu Hurairah RA that the Prophet Muhammad salallahu "alayhi wasalam said," Give a will to women with a better will". ${ }^{24}$

Narrated by Ibn Majah from Ibn Abbas radhiallahu 'anhu that the Prophet Muhammad salallahu' alayhi wasalam said, "The best person among you is the best person towards his family and I am the best person towards my family". ${ }^{25}$

\section{The Role of Women as Educators}

Science is increasingly important for women when they appear to be mother for their children. In order to be able to give birth to a quality generation, women (mother) must be qualified first. ${ }^{26}$

So that women can play an optimal role as a pillar of life and wonders of the world, of course women must equip themselves with various devices that enable them to appear as great women.

Knowledge is something that makes women great. With knowledge, women will rise in rank. With knowledge, women will be seen to exist. And with knowledge, the position of women in society will never be marginalized.

Science as like light that will illuminate women's footsteps into the future. women of knowledge must be elevated. Conversely, women

${ }^{24}$ Al-Bukhari: no: 5186 dan shahih Muslim: no: 1468.

${ }^{25}$ Ibnu Majah: no: 1977.

${ }^{26}$ Iis Nuraeni Afgandi \& Novi Hidayati Afsari, Ternyata Perempuan Bukan Makhluk Lemah, (Bandung: Ruang Kata, 2011), h. 107. 
who are ignorant and lack knowledge will only be considered as weak creatures who can be empowered, not empowered. ${ }^{27}$

Such as the importance of parent's knowledge, especially the knowledge of a mother who is able to make a child's soul character and character, good or bad, so that the obligation for children's education are directed at both parents when the child is still in the womb until he reaches an adult child. For this reason, it is important for a mother to be smart, good knowledge, so that the mother's temperament falls on the children she is caring for.

Al-Quran and Al-Hadith give a lot of praise to men and women who have achievements in science. In a history mentioned that the Prophet was visited by a group of women who asked the Prophet's willingness to set aside time to get knowledge. ${ }^{28}$

Women's independence in pursuing knowledge is widely explained in several traditions, such as the hadith narrated by Ahmad that the Messenger of Allah cursed women who made themselves similar to men, and vice versa, but was not prohibited from holding similarities in terms of intelligence and charity. ${ }^{29}$

Education is very important for every human being, moral education and even intellectual education, women who are the main educators for children, should women at least have a higher education too, the intelligence of women who are expected to be able to educate their children can also be a reason for the role women as the main and first educators for their children.

Thus, education is the right of every Muslim, and its legal obligation to be implemented. Especially for women, and the law to be implemented. Especially for women, education is very important because women are the main key for the education of their children later. Women are a theme park and an encouraging fire for their children in facing the future. What's more, the women in their life has

\footnotetext{
${ }^{27}$ Iis Nuraeni Afgandi \& Novi Hidayati Afsari, Ternyata Perempuan Bukan Makhluk Lemah, (Bandung: Ruang Kata, 2011), h. 104-106.

${ }^{28}$ Nasaruddin Umar, Teologi Jender: Antara Mitos dan Teks Kitab Suci, (Jakarta : Pustaka Cicero, 2003), h. 185.

${ }^{29}$ Ibid
} 
multifunctionalities, namely as a child, as a wife, and as a mother. And as a mother, women are the main and first educators, who are well prepared will be able to give birth to the best sons and daughters as important pillars of community development, homeland, nation and religion. ${ }^{30}$

As women who are assigned to be the first teacher for their children do not necessarily teach only what they knows, mothers who are able to give birth to an intelligent generation for the homeland and nation must also have intelligence in themselves, for women are not wrong to have an education so they can educate their children.

It often happens that women are not only equal to men as far as intelligence is concerned, but sometimes they are superior to men. The only fragile point in women are the intensity (strength) of their feelings. ${ }^{31}$

In Islam, women are not prohibited from teaching or teaching knowledge that they already know. And if each of us likes to open the history books in the early days of Islam and in its greatness, we can find many names of famous Islamic women who are well-known, smart and clever in science. Not only served as teachers, but many also served as advisers (mufti) in the religious sciences and laws relating to womenhood. ${ }^{32}$

On that basis, if a mother gets her role as an educator then a child has the right to teach in himself, the child has the right to service to develop the ability and social life, in accordance with the culture and personality of the nation, to become good and useful citizens. Children have the right to care and protection, both during the womb and after birth. ${ }^{33}$

${ }^{30}$ Iis Nuraeni Afgandi \& Novi Hidayati Afsari, Ternyata Perempuan Bukan Makhluk Lemah, (Bandung: Ruang Kata, 2011), h. 24.

${ }^{31}$ Murtadha Muthahhari, Filsafat Perempuan dalam Islam, (Yogyakarta: Rausyan Fikr, 2015), h. 155.

${ }^{32}$ Moenawar Chalil, Nilai Perempuan, (Solo: Ramadhani, 1984), h. 68-69.

${ }^{33}$ Nani Suwondo, Kedudukan Perempuan Indnesia: Dalam Hukum dan Masyarakat, (Jakarta: Balai Aksara, 1981), h. 124-125. 
As caregivers and educators who are the main rather than children, the education of mother is very influential in society. Because of that education as broad as possible for women according to their respective traits, is very important. ${ }^{34}$

\section{Islamic Attention to Women's Education}

Islam, since its inception has taught and appreciated the principles of human rights (HAM). Respect and respect for humanity and humanity are the main and important teachings in Islam. Among these basic teachings are about the procedures that must be done by humans in knowledge, charity and relationships (ta'aruf) with fellow human beings and all other God's creatures. ${ }^{35}$

Al-Quran, as a source of Islamic teachings, is a source of teachings that pays much attention to the position of women. It is the Al-Qur'an that upholds the dignity of women when pre-Islamic Arabic culture is so degrading to women that the killing of girls is a reasonable thing to accept. The Al-Qur'an also gave rights to women in the 7th century, something that Western women could not obtain until recently. ${ }^{36}$

One aspect of the idea of equality between men and women in Islam stems from the teaching that all human beings originate from a meeting of men and women. In surah An-Nisa 'verse 1:

It means: "O people, fear your Lord Who created you from yourself, and from Him Allah created his wife; and from both of them God multiplied many men and women. and fear Allah who, by (using) His name, you ask one another, and (maintain) the relationship of friendship. Surely Allah always takes care and watches over you."

A scientist who contemplates this verse states: "The proper thing to believe is that there is no text, old or new, that deals with the

${ }^{34}$ Ibid, h. 250.

${ }^{35}$ Imam Machali. 2013. Islam Memandang Hak Asasi Pendidikan, Media pendidikan, 27 (1), h. 14-15.

${ }^{36}$ Ann Elizabeth Mayer. 1995. Islam and Human Rights, Tradition and Politics, London: Pinter Publishers, h. 94. 
humanity of a woman in all its aspects with such astonishing courage, eloquence, depth and purity as the statement in this verse". ${ }^{37}$

The Al-Qur'an verse teaches human equality, including gender equality and eliminates all inequality originating from differences in sex, race, color, nationality, caste or ethnicity; because all humans ultimately come from one source.

There are still a number of other verses which explain clearly that regarding moral and spiritual development, men and women are on the same level of equality. In calling on believers, the Al-Qur'an often uses the statement "men and women of faith" to emphasize equality between men and women in terms of their obligations, rights, virtues and piety. In Surah Al-Ahzab verse 35 it says:

It means: "Verily Muslim men and women, believing men and women, men and women who remain in their obedience, true men and women, patient men and women, men and women solemn women, men and women who give alms, men and women who fast, men and women who maintain their honor, men and women who say a lot (names) Allah, Allah has provided for them forgiveness and great reward.

Regarding religious obligations the Al-Qur'an recognizes that there are no differences between men and women. Obligations to God and to fellow human beings are the same in many aspects, and therefore their position and status are the same in God's eyes. In Surah An-Nahl verse 97 it says:

It means: "Whoever does righteous deeds, both men and women in a state of faith, then surely we will give them a good life and indeed we will reward them with a reward that is better than what they have done".

If women and men have the same obligations in regard to prayer, paying alms to the poor, and amar makruf nahi munkar, then it is undoubtedly that they should have equal opportunities in education. How might women be able to raise their voice against economic

${ }^{37}$ Raga' El-Nimr, Women In Islamic Law in Mai Yamani, ed. Feminism And Islam legal and literary Perspective, (New York: New York University Press, 1996), h. 91. 
policies that damage or defend beneficial economic changes, participate in good politics or prevent bad politics, if women are not mentally and spiritually prepared for the highest religious obligation. ${ }^{38}$

Also worth remembering is that Islam does not make a difference between worldly obligations and religious obligations. According to Islamic teachings, all obligations, whether related to politics, economy or social welfare in general, are religious obligations, no different from prayer, fasting and social assistance organizations. It can be easily concluded from the verse that men and women should be in an equal position in the field of education.

The Arabs in particular, and the whole world in general were still very backward at that time where there were no organized educational institutions even for men. So the Islamic attitude towards women's education can be learned only from the simple sayings of the Prophet and his attitude which gives permission for women to come forward before their freely to ask questions about religious, economic and social interests. The Prophet Muhammad's hadith related to the following signals of equal rights in education between men and women:

Meaning: Ahmad bin Mani 'told us. He said: Hammad bin Khalid alKhayyath told us. From Abdullah bin Umar, From Ubaidillah bin Umar, From al-Qasim bin Muhammad, From Aisyah R.A. He said: Rasulullah SAW. asked about a man who found (used) wet (in his pants), but he did not remember if he (had) dreamed? He answered: He (obliged) to bathe, and about men who dream but he does not find (used) wet. He replied: he was not (obliged) to take a shower. Umm Salamah R.A. said: Yes Rasulallah, do women (obliged) take a bath if they see it that way too? He said: Yes, actually women are siblings (hemispheres) of men. (H.R. Tirmizi). ${ }^{39}$

\footnotetext{
${ }^{38}$ Raga' El-Nimr, Women In Islamic Law in Mai Yamani, ed. Feminism And Islam legal and literary Perspective, (New York: New York University Press, 1996), h. 92.

${ }^{39}$ Muhammad bin Isa at-Tirmizi. 1975. Sunan at-Tirmizi, No. 113, (Mesir: Mushthafa Al-Baby Al-Halaby, 1975), h. 190.
} 
His own wife, Aisha, was a highly educated woman, and during the reign of the four caliphs, her suggestions, even on political matters, were requested by the authorities. Until now she is also recognized as having great authority in the field of Islamic law. One of her students, 'Urwa ibn al-Zubair, testified of her position in knowledge: "I have never seen a scholar who is greater than Aisha in his knowledge of the Al-Qur'an, religious obligations, legal matters or those that are legal illegitimate according to law, poetry and literature, history and Arabic genealogy".

Urwa was a great scholar in the field of literature. One time when he praised Aisha, he stated that no one was equal to Aisha. He was one of the great narrators of the hadiths of the Prophet. He has narrated as many as 2210 hadiths. ${ }^{40}$

Sayyida Nafisa, a descendant of Ali, the fourth caliph, was also a great scholar. Imam Shafi'I was a founder of the Shafi'i school of Islamic law, was one of his famous students who sat in his teaching majors at al-Fustat when he was at the peak of his fame. Sheikha Shuhda, who gave public instruction in one of the most important mosques in Baghdad to such a large audience on centrality, rhetoric and poetry, was also one of the leading scholars in Islam. ${ }^{41}$

There are still many other educated Muslim women who become teachers, writers and writers, and receive such high respect from the Muslim community. These female scholars have always been figures who inspired Muslim women to try to surpass them. The teachings of Al-Qur'an, as well as the History of leading Muslim women are also always a foundation for Muslim feminists in fighting for education for women. ${ }^{42}$

Rich and complex Islamic traditions offer today's women many examples that inspire intellectually, culturally and politically. All this

${ }^{40}$ Ibid. h. 93.

${ }^{41}$ Maha Azzam, Gender And The Politics of Religion In The Middle East in Mai Yamani, ed. Feminism And Islam legal and literary Perspective, (New York: New York University Press, 1996), h. 221.

${ }^{42}$ Margot Badran, Feminist, Islam, and Nation, Gender and The Making of Modern Egypt, (New Jersey: Princeton University Press, 1995), h. 145. 
adds to the emphasis on women's rights in education and public participation, and heightens their sense of depth and pride as Muslims.

Therefore, there are always encouragement for a Muslim women to continue their education in any field for their intellectual interests and to utilize their academic or professional education for the good of society. ${ }^{43}$

\section{Conclusion}

Although normatively Islam has given equal rights for women to get education as well as men, in reality there are still many imbalances in their implementation, especially in Muslim countries. Creating conditions that support, both socially and culturally for women to get their rights in the field of education. The more empowered women are in education, the better the younger generation is born, because the growth of the new generation is in the hands of women (mother).

\section{Daftar Pustaka}

Ali Akbar. Merawat Cinta Kasih. Jakarta: Pustaka Antara, 1978.

Ann Elizabeth Mayer. Islam and Human Rights, Tradition and Politics, London: Pinter Publishers, 1995.

Fauzie Nurdin. Perempuan Islam dan Transformasi Sosial Keagamaan, Yogyakarta: Gama Media, 2009.

Hadi Dust Muhammadi. Bukan Perempuan Biasa, Jakarta: Cahaya, 2005. Hamid Laonso dan Muhammad Jamil. Hukum Islam Alternatif Solusi terhadap Masalah Fiqh Kontemporer, Jakarta: Restu Ilahi, 2005.

Hussein Muhammad. Islam Agama Ramah Perempuan, Yogyakarta: LKiS, 2004.

${ }^{43}$ Raga'El-Nimr, Women In Islamic Law in Mai Yamani, ed. Feminism And Islam legal and literary Perspective, (New York: New York University Press, 1996), h. 93. 
Iis Nuraeni Afgandi \& Novi Hidayati Afsari. Ternyata Perempuan Bukan Makhluk Lemah, Bandung: Ruang Kata, 2001.

Imam Machali. Islam Memandang Hak Asasi Pendidikan, Media pendidikan, 27 (1), 2013.

Isnaniah dan M. Imamuddin. Students' Understanding of Mathematical Concepts Using Manipulative Learning Media in Elementary Schools, Proceeding, $1^{\text {st }}$ Bukittinggi International Conference on Education, IOP Conf. Series Journal of Physics: Conf. Series 1471 (2020) 010250. IOP Publishing doi: 10.1088/17426596/1471/1/012050, 2020.

Kartini Kartono. Psikologi Perempuan, Mengenal Gadis Remaja dan perempuan Dewasa, Bandung: Mandar Maju, 1989.

Khofifah Indar Parawansa. Islam, NU, dan Keindonesiaan, Bandung: Nuansa Cendikia, 2013.

M. Imamuddin, dkk. Islamic Education In The Al-Our'an and Sunnah (Study About the Meaning of Education and Implication for Educator). Journal Educative: Journal of Educational Studies 5 (1), 70-83, 2020.

M. Imamuddin, dkk. Gender Based Perception On Understanding Mathematics Concep By Using PBL, Humanisma: Journal of Gender Studies, 3 (1), 58-74, 2019.

M. Imamuddin dan Isnaniah. Kemampuan Spasial Mahasiswa Laki-laki dan Perempuan dalam Menyelesaikan Masalah Geometri, Humanisma: Journal of Gender Studies, 1 (2), 38-47, JuliDesember 2017.

Maha Azzam. Gender And The Politics of Religion In The Middle East in Mai Yamani, ed. Feminism And Islam legal and literary Perspective, New York: New York University Press., 1996.

Mansour Fakih. Analisis Gender dan Transformasi Sosial, Cet. IX, Yogyakarta: Pustaka Pelajar, 2005. 
Margot Badran. Feminist, Islam, and Nation, Gender and The Making of Modern Egypt, New Jersey: Princeton University Press, 1995.

Moenawar Chalil. Nilai Perempuan, Solo: Ramadhani, 1984.

Muhammad bin Isa at-Tirmizi. Sunan at-Tirmizi, No. 113, Mesir: Mushthafa Al-Baby Al-Halaby, 1975.

Muhammad Munir Mursi. al-Tarbiyyat al-Islamiyat, Ushuliha wa Thathawuriha fi al-Bilad al-Arabiyat, Kairo: 'Alim al-Kutub, 1982.

Murtadha Muthahhari. Filsafat Perempuan dalam Islam, Yogyakarta: Rausyan Fikr, 2015.

Murtadla Muthahari. Hak-hak Perempuan dalam Islam, Jakarta: Lentera, 1995.

Nani Suwondo. Kedudukan Perempuan Indnesia: Dalam Hukum dan Masyarakat, Jakarta: Balai Aksara, 1981.

Nasaruddin Umar. Teologi Jender: Antara Mitos dan Teks Kitab Suci, Jakarta : Pustaka Cicero, 2003.

Raga' El-Nimr. Women In Islamic Law in Mai Yamani, ed. Feminism And Islam legal and literary Perspective, New York: New York University Press, 1996.

Samsul Nizar dan Zainal Efendi Hasibuan. Hadis Tarbawi Membangun Kerangka Pendidikan Ideal Perspektif Rasulullah, Jakarta: Kalam Mulia, 2011.

Supardin. Kajian Gender Perspektif Hadis Nabi, Kajian Gender Perspektif Hadis Nabi, AL-FIKR, Volume 4817 Nomor 1 Tahun 2013.

Syafiq Hasyim. Pengantar Feminisme dan Fundamentalisme Islam, Cet. I, Yogyakarta: LKiS. , 2005.

Trisakti Handayanirakat. Memperjuangkan Hak Asasi Perempuan, dalam Suara Perempuan, Pusat Studi Perempuan dan Kemasyarakatan, Malang: UMM, 1996. 